\title{
Biological and environmental profiling of three Philippine Tetrastigma species (Vitaceae) in northeastern Cagayan, Luzon, Philippines
}

\author{
JEFF M. OPEÑA ${ }^{1,2, \boldsymbol{v}}$, CHARLOT L. MARAMAG ${ }^{3}$, CALIXTO B. ALICAY ${ }^{1}$, MARVIN V. BALOLOY ${ }^{1}$, \\ CLARIBEL A. GASPAR ${ }^{1}$, FROILAN A. PACRIS JR. ${ }^{1}$, JEAN S. TORRES ${ }^{2}$, LYLE B. SUMER ${ }^{1}$, \\ GERLIE U. BAYANI ${ }^{1}$, RACHEL C. SOTTO ${ }^{4}$ \\ ${ }^{1}$ College of Agriculture, Cagayan State University-Gonzaga Campus, Flourishing, Gonzaga, Cagayan, Philippines, \\ "email: jmopena@csu.edu.ph; jmopena@up.edu.ph \\ ${ }^{2}$ Research and Extension Office, Cagayan State University-Gonzaga Campus, Flourishing, Gonzaga, Cagayan, Philippines \\ ${ }^{3}$ College of Information and Computing Sciences, Cagayan State University-Gonzaga Campus, Flourishing, Gonzaga, Cagayan, Philippines \\ ${ }^{4}$ Institute of Biological Sciences, College of Arts and Sciences, University of the Philippines Los Baños, College, Los Baños, Laguna, Philippines
}

Manuscript received: 10 March 2021. Revision accepted: 29 April 2021.

\begin{abstract}
Opeña JM, Maramag CL, Alicay CB, Baloloy MV, Gaspar CA, Jr Pacris FA, Torres JS, Sumer LB, Bayani GU, Sotto RC. 2021. Biological and environmental profiling of three Philippine Tetrastigma species (Vitaceae) in northeastern Cagayan, Luzon, Philippines. Biodiversitas 22: 2956-2970. Tetrastigma species have considerable attention because of their medicinal importance, but little is known about these Philippine species. This study provides information on the biological (morphological, phytochemicals, nutritional, antimicrobial characterization) and environmental (diversity, distribution, growing environment, soil characteristics) profiles of the three Philippine Tetrastigma species namely, Tetrastigma ellipticum Merr., Tetrastigma harmandii Planch., and Tetrastigma loheri Gagnep. Tetrastigma harmandii growing in various habitats were widely distributed throughout northeastern Cagayan, while $T$. ellipticum and T. loheri were found only in the mountain forests of the northernmost part of northeastern Cagayan. Tetrastigma ellipticum was found only in Mt. Cagua forests and volcano, while T. loheri was found growing in the forests of Palaui Island, Buwacag mountain, and Mt. Cagua. Most of the plant species growing within the Tetrastigma environments were native and endemic trees. Mountain species of Tetrastigma (T. ellipticum and T. loheri) grew in extremely acidic soils with high organic matter content. More secondary metabolites were detected in T. ellipticum, which was the only species among the three Tetrastigma species to contain alkaloids, flavonoids, and anthocyanin. Saponins were detected only in T. harmandii. Steroids were not detected in the three species. Moreover, T. harmandii was the only species to have an antibacterial property against Staphylococcus aureus and a slight inhibiting activity against Klebsiella aerogenes. Between the two edible Tetrastigma species, T. harmandii contains more macronutrients and micronutrients, while $T$. loheri contains higher crude protein, crude fat, and crude fiber.
\end{abstract}

Keywords: Chemical, antimicrobial, distribution, habitats, Tetrastigma ellipticum, Tetrastigma harmandii, Tetrastigma loheri

\section{INTRODUCTION}

Tetrastigma (Miq.) Planch is one of the most speciesrich genera of the economically and agronomically important Vitaceae family (Habib et al. 2017). The genus is characterized by its unbranched to digitately branched tendrils, dioecious sexual system, and 4-lobed stigmas in female flowers (Chen et al. 2011). Tetrastigma is also famous in Southeast Asia for being the host plant of the Rafflesia (Wen 2007; Lianah et al. 2015) where Tetrastigma harmandii was reported as the single host plant of Rafflesia lagascae (as R. manillana) on Mt. Makiling, Laguna, Philippines (Yahya et al. 2010). Tetrastigma species grow suitably in hillsides and valleys of shady and moist primary rainforests (Lianah et al. 2015). In the Philippines, there are about 24 species of Tetrastigma, of which 15 species are endemic. Species of the genera exhibited divergences with other Asian species at various times (Wen et al. 2013). Diversity, morphological characteristics, and geographical distribution of Tetrastigma species in the Philippines were reported by Wen et al. (2013) and Pelser et al. (2016).
Recently, other Tetrastigma species have been subjected to pharmacological and phytochemical studies. Modern pharmacological studies showed that $T$. hemsleyanum had a wide range of pharmacological functions such as antiproliferative, antitumor, antivirus, anti-inflammatory, antidiabetic, liver protective, and immunoregulation activities (Zhong, et al. 2006; Xu et al. 2008; Yang and Wu, 2009; Ma et al. 2012; Wang et al. 2018; Ding et al. 2019; Ru et al. 2019). Tetrastigma glabratum plant extract was found to contain steroids, terpenoids, flavonoids, saponins, and tannins (Lianah et al. 2015), while leaves of $T$. leucostaphylum contained alkaloids, phytosteroids, saponin, diterpenes, cardiac glycosides, carbohydrate, fixed oils, and fats (Adarsh et al. 2013). Common Philippine Tetrastigma species specifically the $T$. harmandii is used as a souring ingredient for fish (Maghirang et al. 2018) and was found to have antiscabies, diuretic properties (Brown, 1920) and could treat urinary diseases (Quisumbing, 1951; Carag and Buot, 2017).

However, underutilized Philippine plant species such as the Tetrastigma have been given low priority in most research and development programs. Little is known about 
their utilization, geographical extent, morphological variation, and potential in terms of medicine and food. Also, Tetrastigma plants are not commonly known by the local people due to limited information. Thus it is important to document the distribution and diversity of Tetrastigma as well as the morphological, phytochemical, medicinal, and nutritional properties of Tetrastigma species found in the country.

To contribute to the database about the Tetrastigma species in the Philippines, exploratory trips had to be conducted to determine the existence and distribution of Tetrastigma species in various municipalities of northeastern Cagayan, Philippines. Additionally, it hopes to look into the Tetrastigma species growing in protected areas of northeastern Cagayan such as the Palaui Island Protected Landscape and Seascape (an island in the northeastern extremity of Luzon) in Santa Ana, Cagayan and Mt. Cagua (an active volcano lying in the eastern border of the municipality of Gonzaga, Cagayan which is part of the Sierra Madre range in the eastern coast of Luzon). Documentation of the morphology and growing environment to include the soil characteristics and the plants that grow within the Tetrastigma environment need to be carried out. This study also aimed to investigate the phytochemical and antimicrobial properties of the three Philippine Tetrastigma species. Furthermore, it sought to determine the nutritional content of the two common edible species, T. harmandii, and T. loheri. Hence, this study will be a great help to prepare strategies for conservation, propagation, and eventually in the commercialization of these underutilized Tetrastigma species.

\section{MATERIALS AND METHODS}

\section{Prior Informed Consent (PIC) and selection of local researchers}

To satisfy the legal requirements of EO 247 (Bioprospecting) and RA 9147 (Wildlife Resources Conservation and Protection Act), prior informed consent from the Local Government Units (LGUs) through the Office of the Municipal Mayor, Municipal Environment and Natural Resources Office (MENRO) and the community/barangay was obtained through letters asking for permission to conduct the research and collect plant and soil samples in the identified areas. Moreover, a gratuitous permit was secured from the Department of Environment and Natural Resources Region 2 Office for conducting the study in Mt. Cagua and Palaui Island Protected Landscape and Seascape. Selection of local researchers (forest guides, MENRO and Barangay officials, Coast Guards) was made with the stakeholders in different municipalities of northeastern Cagayan based on their indigenous knowledge of the Tetrastigma species resources in the study sites. The local researchers per municipality were involved during the fieldwork in their respective areas.

\section{Sampling site description}

The municipalities in northeastern Cagayan, Philippines namely Lal-lo, Camalaniugan, Aparri, Buguey, Santa
Teresita, Gonzaga, and Santa Ana were visited for the presence of Tetrastigma species. Northeastern Cagayan experienced a dry season from March to July, while the wet season occurs from September to January. We assessed habitats and environments where the Tetrastigma species grew. The presence of Tetrastigma species was investigated in various habitats (sole or combination). The latitude, longitude, and elevations were recorded using the Geocam Pro version 5.34 (Wazar-Apps, 6 Place Jacques Bonsergent 75010 Paris, France) and a geographical map was generated using Google Earth Pro.

\section{Sampling methods}

The study encountered 49 accessions (in population) of Tetrastigma species in 7 municipalities, namely Lal-lo, Aparri, Camalaniugan, Buguey, Santa Teresita, Gonzaga, and Santa Ana. About 5 accessions of T. ellipticum, 36 accessions of $T$. harmandii, and 8 accessions of $T$. loheri were collected. Accession number coding follows the year of collection and collection number. The accessions were planted in the Cagayan State University-Gonzaga Tetrastigma field gene bank and nursery. The species were located in different barangays of the municipalities (Table 1). A combination of walk/vehicular ride, visual encounter, and photo documentation was carried out from June to October 2020.

\section{Identification and morphological description of the Tetrastigma species}

Morphological identification of the Tetrastigma species by referring to the species description was further performed according to Pelser et al. (2016). During the sampling, the following morphological characters were recorded: old stem shape and appearance, leaf characteristics such as leaf organization, young leaf color, number of leaflets, leaflet shape, leaf margin, type of venation on the adaxial surface, presence of leaf and petiole indumentum, and tendril morphology (Table 2).

\section{Multivariate analysis of the Tetrastigma species}

Visualization of the morphological similarities/ differences among the Tetrastigma species and their populations in northeastern Cagayan was done through Principal Coordinate Analysis (PCoA) based on Euclidean distance and Bray-Curtis similarity index. Principal Coordinate Analysis (PCoA) was done using the Paleontological Statistics Software (PAST 4.03) (Hammer et al. 2001).

\section{Environmental analysis}

The plant species growing within the Tetrastigma species-environment were identified. The scientific name, English name, and common/local name were provided. Characteristics of soils where the Tetrastigma species grew were also determined. Soil samples where the Tetrastigma species grew were collected in various experimental sites. Topsoils were gathered, pulverized, subjected to air-drying at room temperature until total dryness, and were analyzed according to the method outlined by Motsara and Roy (2008). The soil $\mathrm{pH}$, organic carbon (OM), available phosphorus, 
available potassium, and trace elements such as copper, zinc, iron, manganese were tested through the Potentiometric method, Walkey and Black Spectrophotometric, Olsen's method, Cold Sulfuric Extraction, and DTPA extraction, respectively. Interpretation of soil test results was guided by the rating scales of Horneck et al. (2011) for total N, total $\mathrm{P}$, and total $\mathrm{K}$, while the rating scales of Motsara and Roy (2008) were used for the $\mathrm{pH}$ and micronutrients.

Table 1. List of characterized Tetrastigma accessions and their place of collection

\begin{tabular}{|c|c|c|c|c|c|c|}
\hline $\begin{array}{c}\text { Accession } \\
\text { number }\end{array}$ & Species & Collection site & Latitude & Longitude & $\begin{array}{c}\text { Elevation } \\
\text { (m asl.) }\end{array}$ & Population-specific characters \\
\hline $20-001$ & \multirow[t]{4}{*}{ T. harmandii Planch. } & \multirow[t]{4}{*}{ Aparri, Cagayan } & $18.3797^{\circ} \mathrm{N}$ & $121.575^{\circ} \mathrm{E}$ & 42.06 & \\
\hline $20-002$ & & & $18.3803^{\circ} \mathrm{N}$ & $121.58102^{\circ} \mathrm{E}$ & 45.11 & \\
\hline $20-003$ & & & $18.3801^{\circ} \mathrm{N}$ & $121.579^{\circ} \mathrm{E}$ & 18.90 & \\
\hline $20-004$ & & & $18.3807^{\circ} \mathrm{N}$ & $121.581^{\circ} \mathrm{E}$ & 28.04 & \\
\hline $20-006$ & \multirow[t]{2}{*}{ T. harmandii Planch. } & \multirow{2}{*}{$\begin{array}{l}\text { Camalaniugan, } \\
\text { Cagayan }\end{array}$} & $18.2646^{\circ} \mathrm{N}$ & $121.6613^{\circ} \mathrm{E}$ & 35.97 & \\
\hline $20-007$ & & & $18.2644^{\circ} \mathrm{N}$ & $121.6611^{\circ} \mathrm{E}$ & 41.15 & \\
\hline $20-008$ & \multirow[t]{4}{*}{ T. harmandii Planch. } & \multirow[t]{4}{*}{ Buguey, Cagayan } & $18.19613^{\circ} \mathrm{N}$ & $121.83661^{\circ} \mathrm{E}$ & 53.95 & \\
\hline $20-009$ & & & $18.19648^{\circ} \mathrm{N}$ & $121.83664^{\circ} \mathrm{E}$ & 49.07 & \\
\hline $20-010$ & & & $18.18765^{\circ} \mathrm{N}$ & $121.84537^{\circ} \mathrm{E}$ & 50.90 & \\
\hline $20-011$ & & & $18.27522^{\circ} \mathrm{N}$ & $121.86894^{\circ} \mathrm{E}$ & 46.94 & \\
\hline $20-012$ & \multirow[t]{6}{*}{ T. harmandii Planch. } & \multirow{6}{*}{$\begin{array}{l}\text { Sta. Teresita, } \\
\text { Cagayan }\end{array}$} & $18.2299^{\circ} \mathrm{N}$ & $121.88542^{\circ} \mathrm{E}$ & 43.89 & \multirow{6}{*}{$\begin{array}{l}\text { Light green young and mature } \\
\text { leaves }(T . \text { harmandii) }\end{array}$} \\
\hline $20-014$ & & & $18.22839^{\circ} \mathrm{N}$ & $121.8835^{\circ} \mathrm{E}$ & 52.12 & \\
\hline $20-015$ & & & $18.21513^{\circ} \mathrm{N}$ & $121.87775^{\circ} \mathrm{E}$ & 52.12 & \\
\hline $20-016$ & & & $18.21561^{\circ} \mathrm{N}$ & $121.879^{\circ} \mathrm{E}$ & 49.99 & \\
\hline $20-017$ & & & $18.20853^{\circ} \mathrm{N}$ & $121.90755^{\circ} \mathrm{E}$ & 56.08 & \\
\hline $20-018$ & & & $18.23117^{\circ} \mathrm{N}$ & $121.9505^{\circ} \mathrm{E}$ & 74.07 & \\
\hline $20-019$ & \multirow[t]{4}{*}{ T. harmandii Planch. } & \multirow[t]{4}{*}{ Gonzaga, Cagayan } & $18.29163^{\circ} \mathrm{N}$ & $122.1074^{\circ} \mathrm{E}$ & 181.97 & \multirow{4}{*}{$\begin{array}{l}\text { Light green mature leaves with } \\
\text { conspicuous yellow midrib (20- } \\
020 T \text {. harmandii) }\end{array}$} \\
\hline $20-020$ & & & $18.28507^{\circ} \mathrm{N}$ & $122.1114^{\circ} \mathrm{E}$ & 152.10 & \\
\hline $20-021$ & & & $18.28415^{\circ} \mathrm{N}$ & $122.11287^{\circ} \mathrm{E}$ & 146.91 & \\
\hline $20-022$ & & & $18.28517^{\circ} \mathrm{N}$ & $122.11428^{\circ} \mathrm{E}$ & 134.11 & \\
\hline $20-023$ & T. ellipticum Merr. & \multirow{7}{*}{$\begin{array}{l}\text { Mt. Cagua, } \\
\text { Gonzaga, Cagayan }\end{array}$} & $18.21905^{\circ} \mathrm{N}$ & $122.11102^{\circ} \mathrm{E}$ & 828.14 & \multirow{4}{*}{$\begin{array}{l}\text { Dark green mature leaves with } \\
\text { visible yellow spots }(20-027 T \text {. } \\
\text { ellipticum })\end{array}$} \\
\hline $20-024$ & T. ellipticum Merr. & & $18.21688^{\circ} \mathrm{N}$ & $122.11425^{\circ} \mathrm{E}$ & 862.89 & \\
\hline $20-025$ & T. ellipticum Merr. & & $18.21934^{\circ} \mathrm{N}$ & $122.11172^{\circ} \mathrm{E}$ & 818.98 & \\
\hline $20-026$ & T. loheri Gagnep. & & $18.2254^{\circ} \mathrm{N}$ & $122.10846^{\circ} \mathrm{E}$ & 937.87 & \\
\hline $20-027$ & T. ellipticum Merr. & & $18.22379^{\circ} \mathrm{N}$ & $122.1033^{\circ} \mathrm{E}$ & 861.97 & \multirow{3}{*}{$\begin{array}{l}\text { Red newly emerged leaves; light } \\
\text { green young fully opened leaves } \\
(T . \text { loheri) }\end{array}$} \\
\hline $20-028$ & T. ellipticum Merr. & & $18.22507^{\circ} \mathrm{N}$ & $122.10024^{\circ} \mathrm{E}$ & 793.09 & \\
\hline $20-029$ & T. loheri Gagnep. & & $18.22634^{\circ} \mathrm{N}$ & $122.09602^{\circ} \mathrm{E}$ & 698.91 & \\
\hline $20-030$ & \multirow{4}{*}{ T. loheri Gagnep. } & \multirow{4}{*}{$\begin{array}{l}\text { Buwacag } \\
\text { mountains, Sta. } \\
\text { Ana, Cagayan }\end{array}$} & $18.39578^{\circ} \mathrm{N}$ & $122.23983^{\circ} \mathrm{E}$ & 152.10 & \multirow{4}{*}{$\begin{array}{l}\text { Light green newly emerged } \\
\text { leaves; light green young fully } \\
\text { opened leaves ( } T . \text { loheri) }\end{array}$} \\
\hline $20-031$ & & & $18.39592^{\circ} \mathrm{N}$ & $122.23999^{\circ} \mathrm{E}$ & 123.14 & \\
\hline $20-032$ & & & $18.39608^{\circ} \mathrm{N}$ & $122.24022^{\circ} \mathrm{E}$ & 156.06 & \\
\hline $20-033$ & & & $18.39538^{\circ} \mathrm{N}$ & $122.23931^{\circ} \mathrm{E}$ & 127.10 & \\
\hline $20-034$ & T. harmandii Planch. & \multirow{3}{*}{$\begin{array}{l}\text { Palaui Island, } \\
\text { Sta. Ana, Cagayan }\end{array}$} & $18.54369^{\circ} \mathrm{N}$ & $122.15144^{\circ} \mathrm{E}$ & 45.11 & \multirow{3}{*}{$\begin{array}{l}\text { Red to reddish-yellow newly } \\
\text { emerged leaves; red to reddish } \\
\text { light green young fully opened } \\
\text { leaves }(T . \text { loheri) }\end{array}$} \\
\hline $20-036$ & T. loheri Gagnep. & & $18.55114^{\circ} \mathrm{N}$ & $122.1505^{\circ} \mathrm{E}$ & 86.87 & \\
\hline $20-037$ & T. loheri Gagnep. & & $18.55207^{\circ} \mathrm{N}$ & $122.14882^{\circ} \mathrm{E}$ & 56.08 & \\
\hline $20-038$ & \multirow[t]{4}{*}{ T. harmandii Planch. } & Lal-lo, Cagayan & $18.13551^{\circ} \mathrm{N}$ & $121.6983^{\circ} \mathrm{E}$ & 100.89 & Undulate, thick, large leaves; \\
\hline 20-039 & & & $18.13625^{\circ} \mathrm{N}$ & $121.70089^{\circ} \mathrm{E}$ & 107.59 & prominent leaf venation and \\
\hline $20-040$ & & & $18.13709^{\circ} \mathrm{N}$ & $121.70284^{\circ} \mathrm{E}$ & 89.00 & lenticels in the old stem $(20-042$ \\
\hline $20-042$ & & & $18.13597^{\circ} \mathrm{N}$ & $121.70593^{\circ} \mathrm{E}$ & 85.95 & T. harmandii) \\
\hline $20-043$ & T. harmandii Planch. & Gonzaga, Cagayan & $18.24956^{\circ} \mathrm{N}$ & $121.99788^{\circ} \mathrm{E}$ & 64.92 & Large rounded old stems (20- \\
\hline $20-044$ & & & $18.25316^{\circ} \mathrm{N}$ & $121.99811^{\circ} \mathrm{E}$ & 66.14 & 043, 20-049 T. harmandii) \\
\hline $20-045$ & & & $18.25275^{\circ} \mathrm{N}$ & $122.00239^{\circ} \mathrm{E}$ & 70.10 & \\
\hline $20-046$ & & & $18.24962^{\circ} \mathrm{N}$ & $122.01225^{\circ} \mathrm{E}$ & 109.12 & \\
\hline $20-047$ & & & $18.24288^{\circ} \mathrm{N}$ & $122.04192^{\circ} \mathrm{E}$ & 187.154 & \\
\hline $20-048$ & & & $18.28612^{\circ} \mathrm{N}$ & $122.01881^{\circ} \mathrm{E}$ & 46.94 & \\
\hline $20-049$ & & & $18.34764^{\circ} \mathrm{N}$ & $122.08643^{\circ} \mathrm{E}$ & 39.93 & \\
\hline $20-050$ & & & $18.35026^{\circ} \mathrm{N}$ & $122.08727^{\circ} \mathrm{E}$ & 63.09 & \\
\hline $20-051$ & T. harmandii Planch. & Sta. Ana, Cagayan & $18.37334^{\circ} \mathrm{N}$ & $122.12352^{\circ} \mathrm{E}$ & 35.05 & \\
\hline $20-052$ & & & $18.41915^{\circ} \mathrm{N}$ & $122.12968^{\circ} \mathrm{E}$ & 32.92 & \\
\hline $20-053$ & & & $18.42862^{\circ} \mathrm{N}$ & $122.12618^{\circ} \mathrm{E}$ & 52.12 & \\
\hline
\end{tabular}


Table 2. Morphological characters of the Tetrastigma species that were measured qualitatively

\begin{tabular}{|c|c|c|}
\hline Character & State & Reference \\
\hline Old stem shape and characteristics & $\begin{array}{l}\text { (1) rounded woody/semi-woody } \\
\text { (2) flat woody/semi-woody } \\
\text { (3) rounded herbaceous } \\
\text { (4) flat herbaceous }\end{array}$ & Habib et al. 2018 \\
\hline Leaf organization & $\begin{array}{l}\text { (1) pinnately trifoliolate } \\
\text { (2) pedately compound } \\
\text { (3) palmately compound }\end{array}$ & Pelser et al. 2016; Habib et al. 2018 \\
\hline Leaflet number of mature leaves & $\begin{array}{l}\text { (1) } 3 \text { leaflets } \\
\text { (2) } 4 \text { leaflets } \\
\text { (3) } 5 \text { leaflets } \\
\text { (4) } 6 \text { leaflets } \\
\text { (5) } 7 \text { leaflets }\end{array}$ & \\
\hline Newly emerged leaf color & $\begin{array}{l}\text { (1) light green } \\
\text { (2) red } \\
\text { (3) reddish yellow }\end{array}$ & \\
\hline Leaflet shape & $\begin{array}{l}\text { (1) elliptical } \\
\text { (2) elliptic-oblong } \\
\text { (3) lanceolate }\end{array}$ & \\
\hline Leaf margin & $\begin{array}{l}\text { (1) serrate } \\
\text { (2) entire } \\
\text { (3) crenate }\end{array}$ & Habib et al. 2018 \\
\hline Type of venation & $\begin{array}{l}\text { (1) cross-venulate } \\
\text { (2) pinnate }\end{array}$ & \\
\hline Leaf and petiole indumentum & $\begin{array}{l}\text { (1) absent } \\
\text { (2) present in the leaf, absent in the petiole } \\
\text { (3) absent in the leaf, present in the petiole } \\
\text { (4) present in both leaf and petiole }\end{array}$ & Habib et al. 2018 \\
\hline Tendril morphology & $\begin{array}{l}\text { (1) forked/branched } \\
\text { (2) unforked/unbranched }\end{array}$ & Pelser et al. 2016; Habib et al. 2018 \\
\hline
\end{tabular}

\section{Biochemical and microbial screening in the Tetrastigma species}

Preparation of the ethanolic leaf extracts

Freshly collected young and mature leaves of the Tetrastigma species were washed thoroughly with running tap water and rinsed thrice with distilled water. The leaves were air-dried at room temperature for 3-4 days and then chopped into smaller pieces. The air-dried leaves were oven-dried at $50^{\circ} \mathrm{C}$ for several hours, ground and pulverized using mortar and pestle, and sieved. The fine powder was then mixed with $90 \%$ ethanol $\left(200 \mathrm{~g} \mathrm{l}^{-1}\right)$ at room temperature and filtered. The crude extracts were collected for phytochemical and microbial analyses.

\section{Phytochemical screening}

The leaf crude extracts were subjected to screening for the presence of the eight secondary metabolites, namely alkaloids, flavonoids, phenols, terpenoids, anthocyanin, tannins, steroids, and saponins. These were determined following the procedures of Guevarra (2005). Phytochemical screening of alkaloids, anthocyanin, flavonoids, phenols, saponins, steroids, tannins, and terpenoids was done through Meyer's test, $\mathrm{NaOH}$ test, Shinoda test, Ferric Chloride test, Froth test, Liebermann-
Burchard reaction, Lead Acetate test, and Salkowski test, respectively.

\section{Microbial sensitivity test}

The ethanolic leaf extracts were subjected to antimicrobial susceptibility test against gram-negative bacteria Escherichia coli, Pseudomonas aeruginosa, Klebsiella pneumoniae, Klebsiella aerogenes, and Acinetobacter baumannii; and gram-positive bacteria, namely Staphylococcus aureus and Enterococcus faecium using the paper disc diffusion method (Guevarra, 2005). Bacterial strains were obtained from the Central Analytical Laboratory of the Cagayan State University, Tuguegarao City, Cagayan, Philippines. The inoculum size of each tested organism was standardized. The standardized inocula were then plated on Mueller-Hinton agar through cotton swabbing and the plates were incubated for $12 \mathrm{~h}$. Six sterilized Whatman No.1 filter paper discs, $6 \mathrm{~mm}$ diameter, were immersed in the ethanolic leaf extracts and the discs were then placed on inoculated Mueller-Hinton agar plates with the bacterial strains. The sample plates containing six paper discs were replicated thrice. The sample plates were then incubated at $37^{\circ} \mathrm{C}$ for $24 \mathrm{~h}$. Zones of inhibition were measured and their corresponding interferences were described following the rating scale of Guevarra (2005). 


\section{Nutritional and mineral analysis}

Young and mature leaves of the known edible Tetrastigma species ( $T$. harmandii and T. loheri) were analyzed following the procedures of Motsara and Roy (2008). The total nitrogen of the Tetrastigma species was determined following the Kjeldahl Jaudber-Gunning method, while the total phosphorus, total potassium, and trace elements (copper, zinc, iron, and manganese) were analyzed using the Vanadomolybdate, Flame Atomic Emission, and Microwave Plasma Atomic Emission Spectroscopy tests, respectively. Moreover, 100 grams of dried leaf tissues were subjected to proximate analysis wherein crude protein content was determined through the Kjeldahl method, while crude fat and crude fiber content were measured through Filter Bag Technique (ANKOM), and calcium content by Titrimetry test. Interpretation of plant tissue analysis results follows the rating scale of Jones (1967).

\section{RESULTS AND DISCUSSION}

\section{Morphological characteristics of the three Tetrastigma species}

This study supplements the information provided by Pelser et al. (2016) on the key morphological features of the three Philippine Tetrastigma species identified in this study. The old stem shape and appearance, leaf appearance and leaflet shapes, leaf margin, type of venation on the adaxial leaf surface, petiole color, and presence of indumentum in the leaf and petiole were reported in this study. On the other hand, characteristics on tendril structure, number of leaflets, and leaf morphology were the same as those observed by Pelser et al. (2016). Key morphological features are presented in Figure 1 and Table 3.
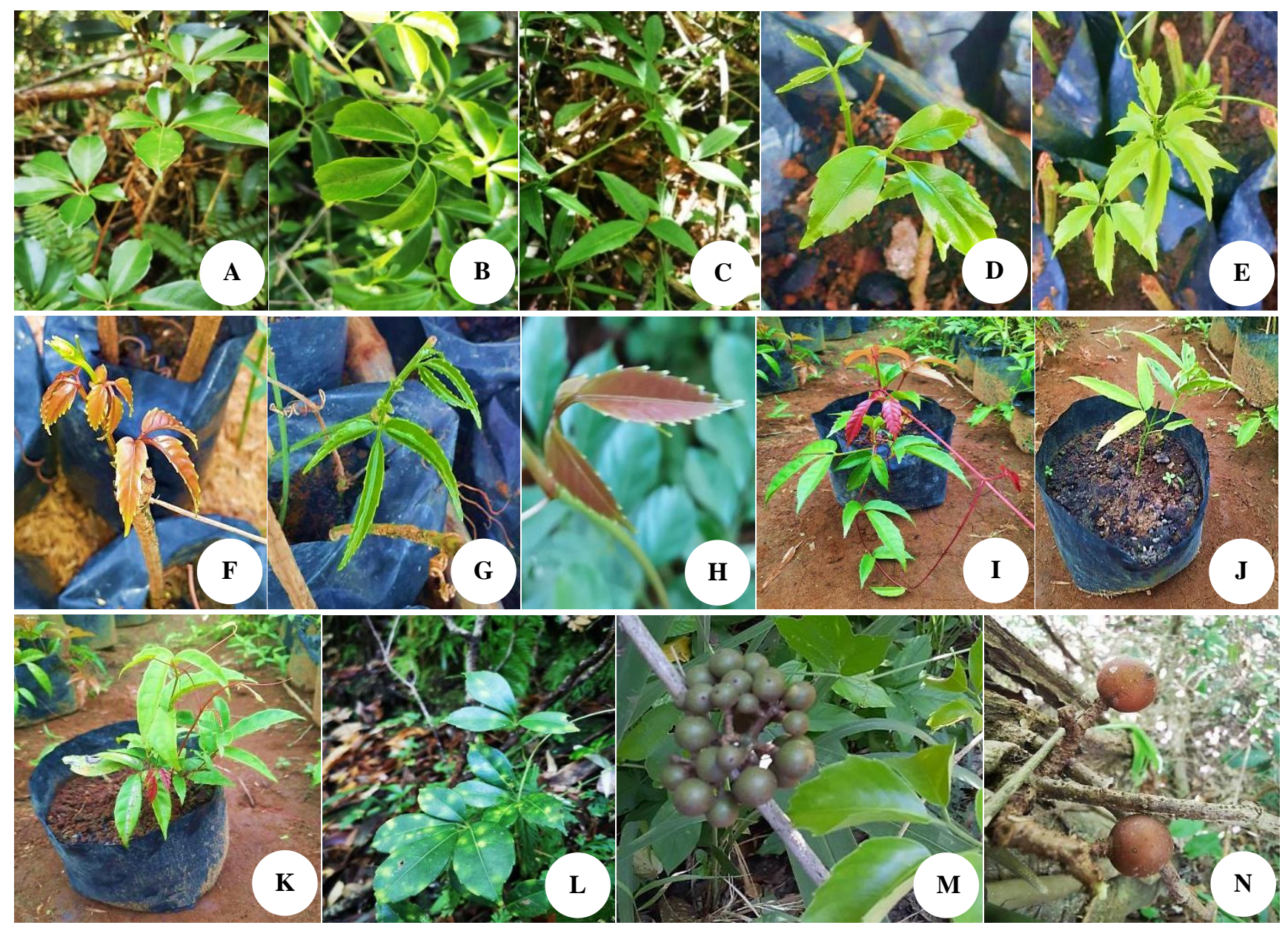

Figure 1. Tetrastigma species growing in the northeastern part of Cagayan, Luzon, Philippines, namely Tetrastigma ellipticum Merr. (A), Tetrastigma harmandii Planch. (B), and Tetrastigma loheri Gagnep (C) which were found in various habitats in Cagayan. Newly emerged leaves of Tetrastigma ellipticum Merr. (D), and Tetrastigma harmandii Planch. (E) were observed during asexual propagation. Newly emerged and young fully opened leaves of Tetrastigma loheri Gagnep found in Palaui Island, Santa Ana (F, I) and Mt. Cagua, Sierra Madre Mountain range in Gonzaga (G, H, J, K) Cagayan have different colors as observed during asexual propagation. A unique accession of Tetrastigma ellipticum Merr. found in Mt. Cagua forest has dark green mature leaves with visible yellow spots (L). Tetrastigma harmandii Planch species in northeastern Cagayan bear young, green, globose (M), and mature, brown, globose fruits (N) during the month of June to October. 
Table 3. Morphological characteristics of three Tetrastigma species growing in various habitats of the northeastern part of Cagayan, Philippines

\begin{tabular}{|c|c|c|c|c|c|c|c|c|}
\hline \multirow[b]{2}{*}{$\begin{array}{l}\text { Scientific } \\
\text { name }\end{array}$} & \multicolumn{8}{|c|}{ Key morphological features } \\
\hline & $\begin{array}{c}\text { Old stem } \\
\text { shape and } \\
\text { characteristics }\end{array}$ & $\begin{array}{l}\text { Leaf morphology and } \\
\text { characteristics }\end{array}$ & $\begin{array}{l}\text { Number of } \\
\text { leaflets }\end{array}$ & $\begin{array}{c}\text { Leaf } \\
\text { margin }\end{array}$ & $\begin{array}{c}\text { Type of venation } \\
\text { on the adaxial } \\
\text { leaf surface }\end{array}$ & Petiole color & $\begin{array}{c}\text { Leaf and } \\
\text { petiole } \\
\text { indumentum }\end{array}$ & Tendril \\
\hline $\begin{array}{l}\text { Tetrastigma } \\
\text { ellipticum } \\
\text { Merr. }\end{array}$ & $\begin{array}{l}\text { Rounded, } \\
\text { semi-woody } \\
\text { to woody } \\
\text { stem }\end{array}$ & $\begin{array}{l}\text { Palmately compound } \\
\text { leaves with glossy. } \\
\text { light to dark green } \\
\text { leaflets } \\
\text { Light green young } \\
\text { leaves } \\
\text { Other plants found } \\
\text { have yellow spots in } \\
\text { the leaves } \\
\text { Elliptical leaflets }\end{array}$ & $3,4,5$ & Serrate & Pinnate & $\begin{array}{l}\text { Young and } \\
\text { mature leaves } \\
\text { have both green } \\
\text { petioles }\end{array}$ & Absent & $\begin{array}{l}\text { Forked/ } \\
\text { branched } \\
\text { tendrils }\end{array}$ \\
\hline $\begin{array}{l}\text { Tetrastigma } \\
\text { harmandii } \\
\text { Planch. }\end{array}$ & $\begin{array}{l}\text { Flat, woody } \\
\text { stem (others } \\
\text { have rounded } \\
\text { stem) }\end{array}$ & $\begin{array}{l}\text { Pedately compound } \\
\text { leaves with glossy } \\
\text { dark green leaflets } \\
\text { Light green young } \\
\text { leaves } \\
\text { Elliptic-oblong } \\
\text { leaflets }\end{array}$ & (3) $5(7)$ & Serrate & Cross-venulate & $\begin{array}{l}\text { Young and } \\
\text { mature leaves } \\
\text { have both green } \\
\text { petioles }\end{array}$ & Absent & $\begin{array}{l}\text { Unforked/ } \\
\text { unbranche } \\
\text { d/ simple } \\
\text { tendrils }\end{array}$ \\
\hline $\begin{array}{l}\text { Tetrastigma } \\
\text { loheri } \\
\text { Gagnep. }\end{array}$ & $\begin{array}{l}\text { Rounded, } \\
\text { semi-woody } \\
\text { to woody } \\
\text { stem }\end{array}$ & $\begin{array}{l}\text { Pinnately trifoliolate } \\
\text { leaves with dark green } \\
\text { leaflets } \\
\text { Light green to reddish } \\
\text { young leaves } \\
\text { Lanceolate leaflets }\end{array}$ & 3 & Serrate & Pinnate & $\begin{array}{l}\text { Young leaves } \\
\text { have green to } \\
\text { reddish petioles } \\
\text { while mature } \\
\text { leaves have } \\
\text { green petioles }\end{array}$ & Absent & $\begin{array}{l}\text { Unforked/ } \\
\text { unbranced } \\
\text { / simple } \\
\text { tendrils }\end{array}$ \\
\hline
\end{tabular}

\section{Tetrastigma ellipticum Merr.}

The plants were encountered in the forests and near the volcano crater of Mt. Cagua, Sierra Madre Mountain range in Gonzaga, Cagayan. Species found in the other areas of Mt. Cagua with an altitude of $861.97 \mathrm{~m}$ asl. had yellow spots in the leaflets. The newly emerged leaves were light green and trifoliolate which could be confused with those of $T$. loheri considering that both species were found in the forests of Mt. Cagua. The only difference in the newly emerged young leaves of T. ellipticum from T. loheri was the broader lamina of its trifoliolate leaves unlike the elongated lamina of the trifoliolate leaves of $T$. loheri (Figure 1, Table 3). The older stem of the T. ellipticum species varied from semi-woody to woody. The species encountered were in their vegetative stage and were not yet flowering or fruiting.

\section{Tetrastigma harmandii Planch.}

Most of the species found in the municipalities of northeastern Cagayan, except in the municipalities of Buguey, Gonzaga, and Lal-lo, had no flowers. In the three municipalities, some of the plants bore fruits (Figure 1) in June to October. The color of the leaves depended on the location. The plants found in the shaded area had darker green leaves compared to those in exposed areas. Some accessions found in Cabiraoan, Gonzaga have light green mature leaves with conspicuous yellow midribs. Also, an accession found in Santa Maria, Lal-lo had unique morphological characters in that the lenticels of the old stem as well as the leaf venation were prominent. It also had undulate, thick, and large leaflets resembling the leaves of Robusta coffee. Tetrastigma harmandii was observed to be the most common Tetrastigma species in Cagayan. The leaves were used as a souring agent in cooking and were known to remove the fishy smell of fish-based dishes.

\section{Tetrastigma loheri Gagnep.}

Tetrastigma loheri species in Mt. Cagua (Sierra Madre Mountain range) in Gonzaga, Palaui Island (Protected Landscape and Seascape), and Buwacag mountains in Santa Ana were morphologically different in terms of young leaf characteristics. Tetrastigma loheri species encountered in the forests and near the volcano crater of Mt. Cagua Sierra Madre Mountain range in Gonzaga had red to light green newly emerged leaves, while species encountered in the mountain forest of Buwacag in Santa Clara, Santa Ana had light green newly emerged leaves (Figure 1, Table 3). However, T. loheri growing in mountain forests of Palaui Island in Santa Ana had red to reddish-yellow newly emerged leaves. The differences in the leaf color of newly emerged leaves were observed in the nursery when plants were propagated through stem cuttings (Figure 1). Plants found in Mt. Cagua, Buwacag mountains, and Palaui Island forests were creeping on the soil and climbing on other plant species. These plants were at the vegetative stage.

\section{Multivariate analysis of the Tetrastigma species growing in northeastern Cagayan}

A Principal Coordinate Analysis (PCoA) was performed to determine the dis(similarity) among the different accessions of Tetrastigma species found in 
various municipalities of northeastern Cagayan (Figure 2). This was based on the morphological characters, namely old stem shape and characteristics, leaf organization, leaflet number of matured leaves, young leaf color, leaf shape and margin, type of venation, leaf and petiole indumentum, and tendril morphology. Using Euclidean similarity index, coordinates 1 (79.507 eigenvalue) and 2 (30.015 eigenvalue) accounted for $60.05 \%$ and $22.67 \%$ variations, respectively. Meanwhile, Bray-Curtis similarity index accounted for $50.27 \%$ and $27.40 \%$ variations for coordinate 1 ( 0.243 eigenvalue) and coordinate 2 ( 0.133 eigenvalue), respectively. Scatter plots showed that $T$. harmandii species found in various municipalities of northeastern Cagayan showed more similarity with $T$. ellipticum accessions found in Mt. Cagua, Gonzaga than the T. loheri accessions found in Gonzaga (Mt. Cagua) and Sta. Ana (Buwacag mountains and Palaui Island), Cagayan. The similarity between $T$. harmandii and $T$. ellipticum was evident due to some morphological characteristics where both species have compound leaves with green petioles, and more than three, light green, elliptical leaflets as opposed to the trifoliolate leaves with light green to reddish, lanceolate leaflets, and green to reddish petioles of the young leaves of $T$. loheri.

PCoA scatter plots also showed differences among $T$. harmandii and $T$. loheri accessions in different localities. Less similarity was shown in some T. harmandii accessions found in Gonzaga due to differences in the old stem shape and characteristics, and leaflet number of matured leaves. On the other hand, T. loheri accessions found in Palaui Island forest, Sta Ana were less similar than those accessions found in Buwacag mountains, Sta. Ana and Mt. Cagua forest, Gonzaga. Less similarity was due to differences in the color of the newly emerged leaves where T. loheri accessions found in Palaui Island have reddishyellow newly emerged leaves as opposed to the light green newly emerged leaves of $T$. loheri accessions found in Buwacag mountains and Mt. Cagua forest. Morphological differences among the accessions within a species may be accounted to the type of habitat or locality where these accessions are growing. These data are important in selecting representative accessions to be included in further Tetrastigma investigations or studies. Further studies showing the similarity of the species based on molecular characteristics are suggested.

\section{Geographical distribution of Tetrastigma species and their environments}

Three species of Philippine Tetrastigma were found in various habitats of northeastern Cagayan, Philippines. In this study, we report the updated preliminary data on diversity, distribution, and growing environment characteristics of the three Tetrastigma species growing in northeastern Cagayan, Philippines. Tetrastigma species distribution in the Philippines was reported in several studies where the three species were said to be widely distributed in Luzon, Visayas, and Mindanao. Reports on the specific location of distribution for T. ellipticum were in Basilan, Panay, and Dinagat while T. loheri was found in Negros, Panay, Samar, Mindoro and Palawan.

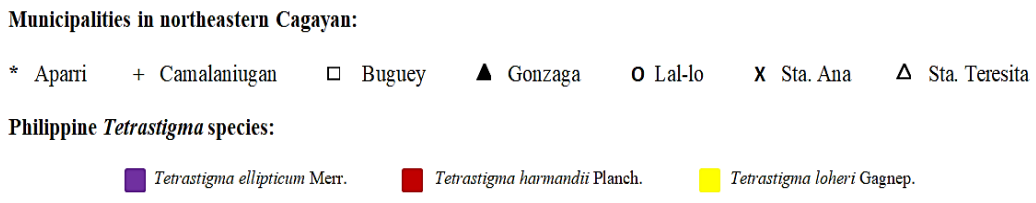

A

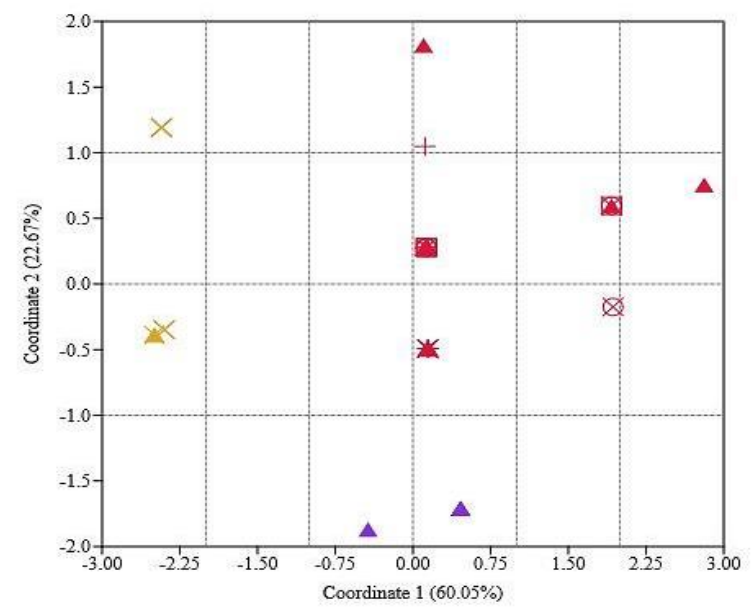

B

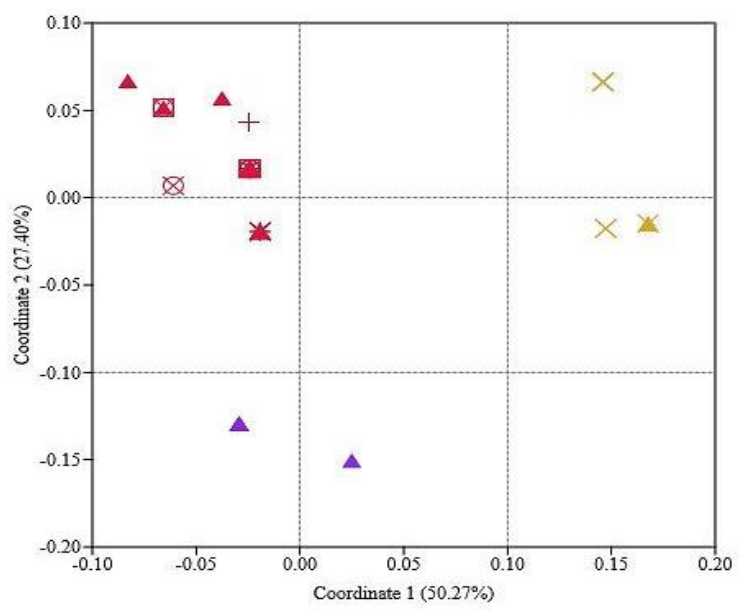

Figure 2. Principal Coordinate Analysis (PCoA) scatter plots of three Tetrastigma species growing in various municipalities of northeastern Cagayan, Luzon, Philippines, based on morphological traits. PCoA was calculated using PAST (Hammer et al. 2001). PCoA plots were computed based on Euclidean (A) and Bray-Curtis (B) similarity indices, transformation exponent c=2 and eigenvalue scale 
Meanwhile, T. harmandii was distributed in Mindoro, Panay, and Negros (Wen et al. 2013; Pelser et al. 2016). The only report in Cagayan Province was in Bolos Point where T. loheri was found (Pelser et al. 2016). The study has encountered these three species of Tetrastigma which were distributed around northeastern Cagayan (Figure 3). This study is the first detailed report on the habitat and growing environment of the three Tetrastigma species. Of the 49 Tetrastigma species accessions encountered during the study, 36 accessions of T. harmandii Planch. species were widespread and found in all municipalities and found growing in various elevations ranging from $18.89 \mathrm{~m}$ asl. to $187.15 \mathrm{~m}$ asl.. This species was found in various habitats, including residential areas, near coastal areas, nipa plantations, agricultural lands planted with rice, corn, and vegetables, grasslands, near water bodies (rivers, creeks, dam, and freshwater spring), secondary forests, outside the caves, and in the community of Palaui Island (Figure 4). However, this species was not found in high elevations such as in Mt. Cagua forests, summit/grassland, and volcano, Palaui Island, and Buwacag mountain forests. Meanwhile, T. ellipticum Merr. and T. loheri Gagnep. were found in the Mt. Cagua forests with high elevations. Tetrastigma ellipticum species were only encountered in Mt. Cagua, Gonzaga, Cagayan (793.08 m asl. to $862.88 \mathrm{~m}$ asl.) and were not found in other forests such as in Santa Ana Buwacag mountains and Palaui Island mountains wherein $T$. loheri also existed. Tetrastigma loheri was found in the forests of Mt. Cagua (698.90 m asl. to 937.86 $\mathrm{m}$ asl.), Buwacag mountains, and Palaui Island $(56.08 \mathrm{~m}$ asl. to $156.05 \mathrm{~m}$ asl.). Tetrastigma loheri and T. ellipticum were highland or mountain species. The same observation was reported by Pelser et al. (2016) where these two species grew mostly in various mountains in the Philippines. Moreover, T. ellipticum and T. loheri were found near the Mt. Cagua volcano crater with high sulfur and high-temperature environment, while $T$. harmandii thrived near coastal areas with saline sandy soil.

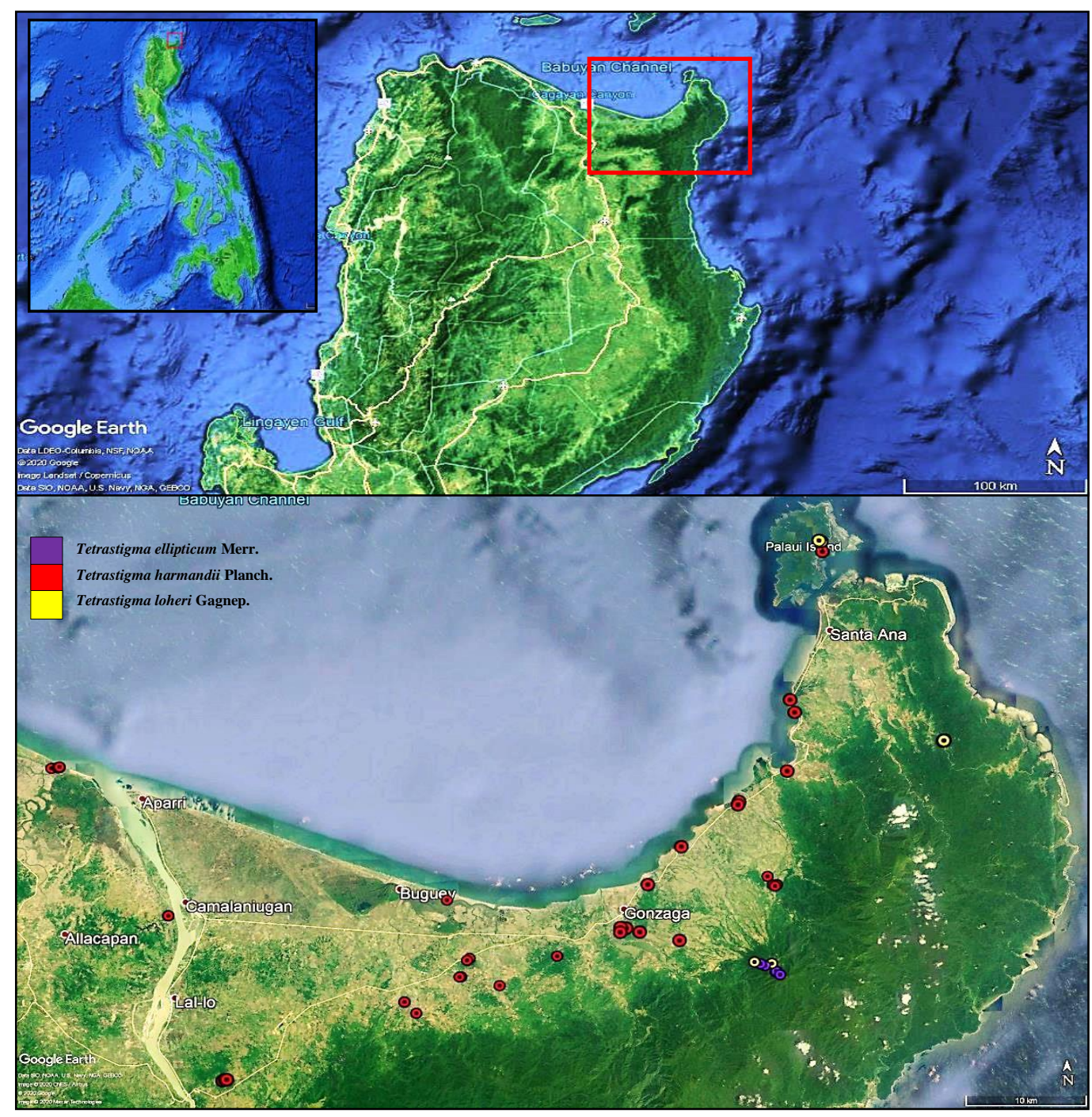

Figure 3. Geographical distribution of three Tetrastigma species in northeastern part of Cagayan, Luzon, Philippines 
The vines of $T$. harmandii were mostly growing on trees such as Melanolepis multiglandulosa (Reinw. Ex Blume) Reichb. \& Zoll. [Alim], Macaranga tanarius (Linn.) Muell.-Arg [Samak], Gliciridia sepium (Jacq.) Kunth ex Walp. [Kakawate], Ficus ulmifolia Lam. [Oplas], Ficus nota (Blanco) Merr. [Tibig], Antidesma bunius (L.) Spreng [Bignay], Hibiscus tiliaceus Linn. [Malabago], Kleinhovia hospita Linn. [Biknong], Coffea robusta Linden [Kape], and other trees. Meanwhile, vines of T. ellipticum and $T$. loheri were mostly encountered as creeping on the soil with other vegetation and climbing on taller plants such as Dillenia philippinensis Rolfe [Katmon], Shorea contorta Vidal [Lauan], Wallaceodendron celebicum Koord. [Banuyo], Calamus rotang Linn. [Rattan], Diplodiscus paniculatus Turcz. [Balobo], Donax canniformis (G. Forst.) K. Schum. [Darumaka], Dracontomelon dao (Blanco) Merr. \& Rolfe [Dao], Ficus nota (Blanco) Merr. [Tibig], Hibiscus tiliaceus Linn. [Malabago], Diospyros philippinensis A. DC. [Kamagong], and other plants (Table 4). T. ellipticum, T. harmandii, and T. loheri were known to be distributed in the regions of Luzon, Philippines (Pelster et al. 2016). In this study, we observed that most of the plant species growing within the Tetrastigma environments were wild bamboo and wild ferns. Other plant species such as agricultural crops, native and endemic species were also found growing nearby and these were believed to provide a favorable growing environment by providing partial shade to the Tetrastigma plants (Table 3).
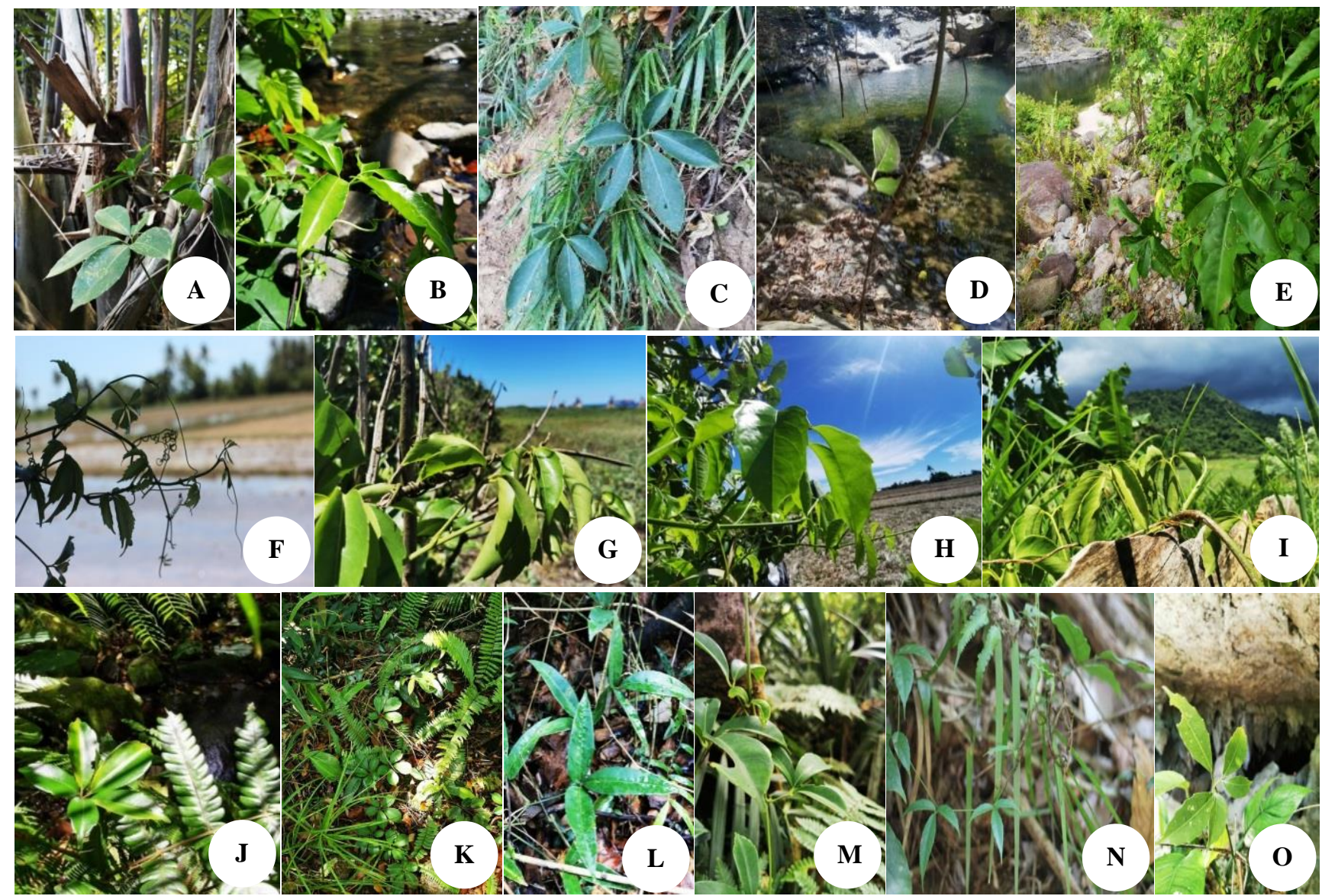

Figure 4. Tetrastigma species growing in various habitats in northeastern Cagayan, Luzon, Philippines. Tetrastigma species were encountered in various habitats such as nipa plantations (A), creeks (B), spring (C), falls (D), dam (E), Cagayan river (F), near coastal areas (G), agricultural lands (H), grasslands (I), Mt. Cagua river (J), Mt. Cagua forests (K, L), near Mt. Cagua volcano crater (M), Palaui Island forests $(\mathrm{N})$, and outside the cave (O). Tetrastigma harmandii Planch. (A-C, E-I, O), Tetrastigma ellipticum Merr. (J, K), and Tetrastigma loheri Gagnep. (D, L, M, N) were found growing in different municipalities of northeastern Cagayan 
Table 4. Geographical distribution and environment of the three Tetrastigma species in the northeastern part of Cagayan, Philippines

\begin{tabular}{|c|c|c|c|c|}
\hline Species & Location & Habitats and ecology & $\begin{array}{l}\text { Latitude-longitude and } \\
\text { elevations (m asl..) }\end{array}$ & Other plants growing within the Tetrastigma environments \\
\hline $\begin{array}{l}\text { Tetrastigma } \\
\text { ellipticum Merr. }\end{array}$ & $\begin{array}{l}\text { Mt. Cagua, Santa Clara, } \\
\text { Gonzaga }\end{array}$ & $\begin{array}{l}\text { High elevation mountain forests } \\
\text { (793.09-862.89 m asl.), } \\
\text { Primary growth forests, } \\
\text { Near the Mt. Cagua creek, } \\
\text { Near the Mt. Cagua volcano } \\
\text { (approx.100 meters below the volcano } \\
\text { crater), } \\
\text { Above the Mt. Cagua falls }\end{array}$ & $\begin{array}{l}18.21^{\circ} \mathrm{N}, 122.11^{\circ} \mathrm{E} \text { to } \\
18.22^{\circ} \mathrm{N}, 122.10^{\circ} \mathrm{E} \\
793.08 \text { to } 862.88 \mathrm{~m} \text { asl. }\end{array}$ & $\begin{array}{l}\text { Dillenia philippinensis } \text { Rolfe [Catmon/Katmon] } \\
\text { Shorea contorta Vidal [Lauan] } \\
\text { Wallaceodendron celebicum Koord. [Narang-dawer, Derahm mahogany/Banuyo] } \\
\text { Pandanus tectorius Parkinson ex Du Roi [Screw pine/Pandan] } \\
\text { Calamus rotang Linn. [Rattan] } \\
\text { Dinochloa dielsiana } \text { Pilger [Bikal-boboi] } \\
\text { Bambusa spp. [Wild bamboo] } \\
\text { Asplenium nidus Linn. [Bird's nest fern/pakpak-lauin] } \\
\text { [Wild ferns] }\end{array}$ \\
\hline $\begin{array}{l}\text { Tetrastigma } \\
\text { harmandii Planch. }\end{array}$ & $\begin{array}{l}\text { Santa Maria, Lal-lo, } \\
\text { Bulala Norte, Aparri, } \\
\text { Babaywan Creek, Juaquin } \\
\text { Dela Cruz, Camalaniugan, } \\
\text { Cagayan river, } \\
\text { Camalaniugan, } \\
\text { Nangatulan Creek, Villa } \\
\text { Cielo, Buguey, } \\
\text { Villa Leonora, Buguey, } \\
\text { Luga, Santa Teresita, } \\
\text { Tabaco Cave, Luga, Santa } \\
\text { Teresita, } \\
\text { Aridowen, Santa Teresita, } \\
\text { Mission, Santa Teresita, } \\
\text { Flourishing, Gonzaga, } \\
\text { Santa Clara, Gonzaga, }\end{array}$ & $\begin{array}{l}\text { Lowland (18.90-74.07 m asl.), } \\
\text { Hills (85.95-181.97 m asl.), } \\
\text { Residential area, } \\
\text { Near from coastal areas (approx. 5- } \\
200 \text { meters away from the sea), } \\
\text { Nipa plantations, } \\
\text { Agricultural lands/Agroecosystem, } \\
\text { Grasslands, } \\
\text { Near from rivers, creeks, dam, } \\
\text { swamp, spring, and irrigation canals, } \\
\text { Outside the cave, } \\
\text { Secondary growth forest } \\
\text { Island shorelines, }\end{array}$ & $\begin{array}{l}18.13^{\circ} \mathrm{N}, 121.69^{\circ} \mathrm{E} \text { to } \\
18.13^{\circ} \mathrm{N}, 121.70^{\circ} \mathrm{E} \\
85.95 \text { to } 107.59 \mathrm{~m} \text { asl. } \\
\\
18.37^{\circ} \mathrm{N}, 121.57^{\circ} \mathrm{E} \text { to } \\
18.38^{\circ} \mathrm{N}, 121.58^{\circ} \mathrm{E} \\
18.89 \text { to } 45.11 \mathrm{~m} \text { asl. } \\
\\
18.26^{\circ} \mathrm{N}, 121.66 \mathrm{oE} \\
35.96 \text { to } 41.14 \mathrm{~m} \text { asl. } \\
\\
18.18^{\circ} \mathrm{N}, 121.84^{\circ} \mathrm{E} \text { to } \\
18.27^{\circ} \mathrm{N}, 121.86 \mathrm{oE} \\
46.93 \text { to } 53.94 \mathrm{~m} \text { asl. }\end{array}$ & 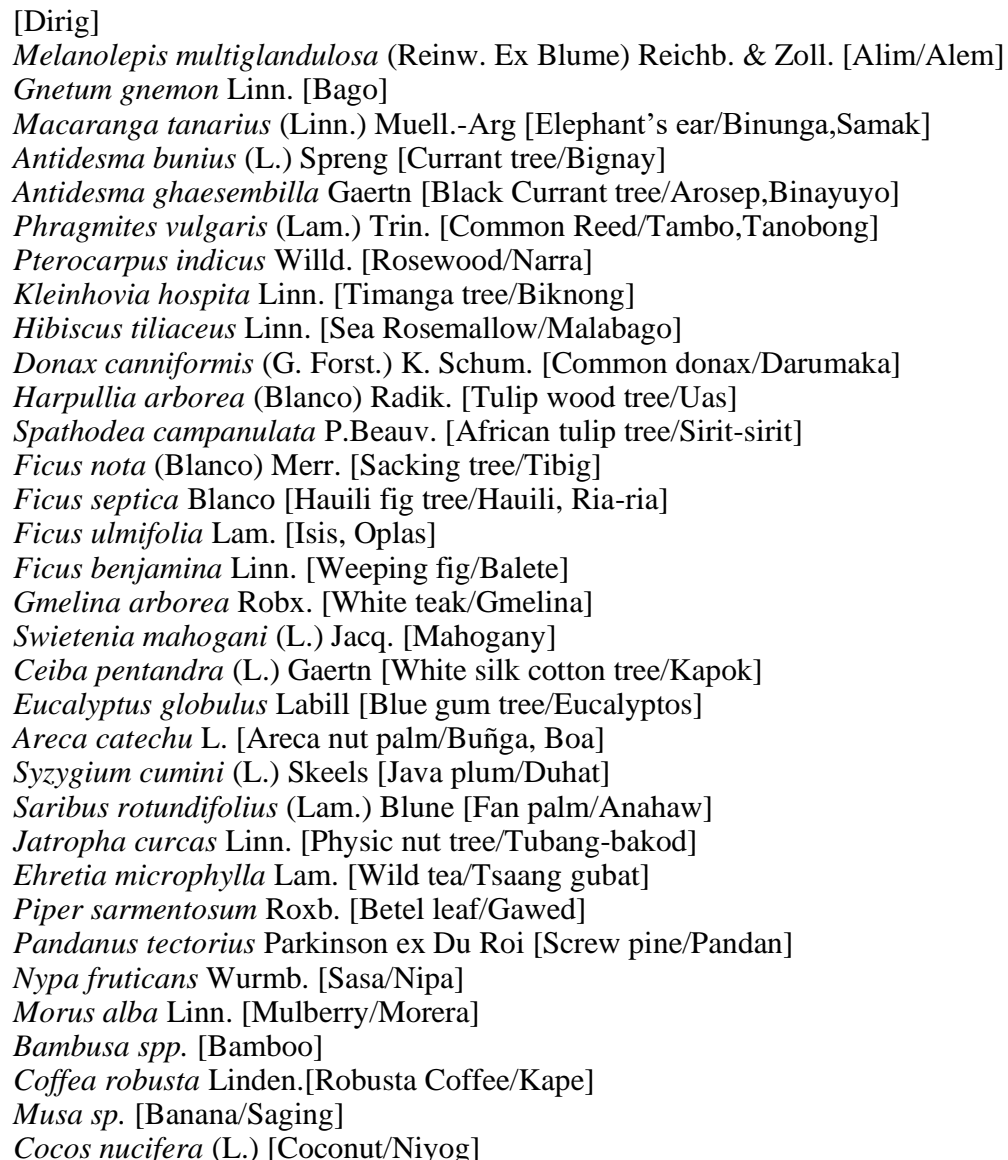 \\
\hline
\end{tabular}


Tetrastigma

harmandii Planch.

Calayan, Gonzaga,

Ipil, Gonzaga

Baua, Gonzaga,

Cabiraoan, Gonzaga,

Casambalangan, Santa

Ana

Racat, Santa Ana

Zinungan, Santa Ana,

Punta Verde, Palaui

Island, San Vicente, Santa

Ana,

Tetrastigma loheri Mt. Cagua, Santa Clara, Gonzaga

Buwacag Falls, Santa Clara, Santa Ana

Punta Verde, Palaui Island, San Vicente, Santa Ana
High elevation mountain fores (698.91-937.87 $\mathrm{m}$ asl.),

Mid elevation mountain forest

(123.14-156.06 $\mathrm{m}$ asl.),

Low elevation mountain forest $\left(56.08-18.39^{\circ} \mathrm{N}, 122.23^{\circ} \mathrm{E}\right.$ to $86.87 \mathrm{~m}$ asl.),

Primary growth forests

$18.55^{\circ} \mathrm{N}, 122.15^{\circ} \mathrm{E}$
56.08 to $156.05 \mathrm{~m}$ asl

ove the volcano crater)

Below the peak of Mt. Cagua,

Near bodies of water (river, falls),

Island,
Artocarpus heterophyllus Lam [Jackfruit/Langka]

Mangifera indica L. [Mango/Mangga]

Carica papaya L. [Pawpaw/Papaya]

Sandoricum koetjape (Burm.f.) Merr.[Lolly fruit/Santol]

Psidium guajava Linn. [Guava/Bayabas]

Tamarindus indica Linn. [Tamarind/Sampalok]

Gliciridia sepium (Jacq.) Kunth ex Walp. [St. Vincent Plum/Kakawate]

Tabernaemontana pandacaqui Poir. [Banana bush/Kampupot]

Chromolaena odorata (L.) R.M. King \& H. Rob. [Siam weed/Hagonoy]

Leucaena leucocephala (Lam.) de Wit [Lead tree/ Ipil-ipil]

Imperata cylindrica (L.) Raeusch [Cogon grass, Speargrass/Kogon,Pan-au]

Dinochloa dielsiana Pilger [Bikal-boboi]

Ipomoea aquatica Forsk. [Water spinach/Kangkong]

Panicum maximum Jacq.[Guinea grass]

Passiflora foetida Linn. [stinking passionflower/Prutas-Baguio]

[Marapapaya]

Capsicum sp. [Wild capsicum]

Solanum torvum Sw. [Turkey berry, Devil's Fig/Tandang-aso]

Colocasia esculenta Linn. [Taro/Gabi]

Tradescantia spathacea Sw. [Moses-in-the-cradle, boat lily/Bangka-bangkaan]

Monstera deliciosa Liebm. [Swiss cheese plant, split-leaf philodendron]

Mucuna pruriens (L.) DC. [Velvet bean/Sabawil]

Centrosema pubescens Benth. [Butterfly pea, Centro/Dilang-butiki]

Mimosa pudica L. (Laajvanti) [Sensitive plant/Makahiya]

[Wild ferns]

$\begin{array}{ll}18.22^{\circ} \mathrm{N}, 122.09^{\circ} \mathrm{E} \text { to } & \text { [Daer] } \\ 18.22^{\circ} \mathrm{N}, 122.10^{\circ} \mathrm{E} & \text { Diplodiscus paniculatus Turcz.[Bagobo, Balobo] }\end{array}$

$\begin{array}{ll}18.22^{\circ} \mathrm{N}, 122.09^{\circ} \mathrm{E} \text { to } & \text { [Daer] } \\ 18.22^{\circ} \mathrm{N}, 122.10^{\circ} \mathrm{E} & \text { Diplodiscus paniculatus Turcz.[Bagobo, Balobo] }\end{array}$

Donax canniformis (G. Forst.) K. Schum. [Common donax/Darumaka]

Shorea contorta Vidal [White lauan]

Dracontomelon dao (Blanco) Merr. \& Rolfe [Pacific Wallnut/Dao]

Ficus nota (Blanco) Merr. [Sacking tree/Tibig]

Hibiscus tiliaceus Linn. [Sea Rosemallow/Malabago]

Diospyros philippinensis A. DC. [Kamagong gubat]

Pterocarpus indicus Willd. [Rosewood/Narra]

Mangifera indica $\mathrm{L}$. [Mango/Mangga]

Artocarpus sp. [Artocarpus]

Citrus limon (L.) Burm. [Lemon]

Calamus rotang Linn. [Rattan]

Dinochloa dielsiana Pilger [Bikal-boboi]

Bambusa spp. [Wild bamboo]

Thysanolaena maxima (Roxb.) [Tiger grass]

Caladium sp. [Wild caladium]

Begonia sp. [Wild begonia]

Spathoglottis plicata Blume [Wild ground orchids]

[Wild ferns] 
Soil characteristics of the Tetrastigma species habitats

The chemical composition of soils where the Tetrastigma species grew is varied (Table 5). Tetrastigma ellipticum species grew in soils with extremely acidic $\mathrm{pH}$ with medium to high organic matter content, low to medium phosphorus content, medium to high potassium content, medium to high copper content, very low to low zinc content, very high iron content, and medium to very high manganese content. On the other hand, T. harmandii species grew in soils with strongly acidic to slightly acidic $\mathrm{pH}$ with low to medium organic matter content, high to excessive phosphorus content, high potassium content, low to high copper content, very low to medium zinc content, high to very high iron and manganese contents. Tetrastigma loheri species grew in soils with extremely acidic to moderately acidic $\mathrm{pH}$ with low to high organic matter content, low to medium phosphorus content, high to excessive potassium content, medium to very high copper content, very low to high zinc content, very high iron and manganese contents.

To compare the species, T. elipticum and T. loheri grew in soils with very low $\mathrm{pH}$, while $T$. harmandii grew in soils with higher $\mathrm{pH}$. The soils where T. ellipticum and T. loheri were found also had higher organic matter content than those of $T$. harmandii. However, the soils where $T$. harmandii grew contained the highest phosphorus while those of $T$. loheri contained the highest potassium. In terms of the micronutrient content, the soils where T. loheri was found had the highest copper, zinc, and moderately high manganese content while T. ellipticum grew in soils with the highest iron content but lowest copper, zinc, and manganese contents.

\section{Phytochemical screening of the Tetrastigma species}

Phenols, tryptophan, and tannins were commonly present while steroids were commonly absent in the three Tetrastigma species (Table 6). Secondary metabolites such as alkaloids, flavonoids, phenols, terpenoids, anthocyanin, and tannins were detected in the leaves of T. ellipticum. Leaves of $T$. harmandii and $T$. loheri contain phenols, terpenoids, and tannins. However, saponins were not detected in $T$. loheri species. Tetrastigma ellipticum differed from other species due to the presence of alkaloids, flavonoids, and anthocyanins, while $T$. loheri and $T$. harmandii lack the aforementioned secondary metabolites. Also, T. ellipticum and T. loheri lack saponins. Among the three Tetrastigma species, only the phytochemical property of T. harmandii was investigated (Agngaryngay et al. 2015, unpublished data). With the above-mentioned findings, the extraction and utilization of secondary metabolites in the Tetrastigma species for pharmaceutical and industrial purposes would be easier since their potential sources were already identified.

\section{Antibacterial properties of the Tetrastigma species}

The antibacterial properties of the three Tetrastigma species in northeastern Cagayan against various gramnegative and gram-positive pathogenic bacteria are presented in Table 7. This is the first study on the antibacterial profiles of the three Philippine Tetrastigma species. Among the three species, only the T. harmandii demonstrated an inhibitory effect on the growth of some bacterial strains such as Staphylococcus aureus and Klebsiella aerogenes with $10 \mathrm{~mm}$ and $9 \mathrm{~mm}$ mean zones of inhibition, respectively. Antibacterial activity of the leaf ethanolic extract of $T$. harmandii demonstrated a partially active reaction against Staphylococcus aureus and a least active reaction in Klebsiella aerogenes. Mountain forest species of Tetrastigma did not show any antibacterial activity against the tested microorganisms. Among the three Tetrastigma species, only the T. harmandii contained saponins which were reported to have antibacterial mechanism against Staphylococcus aureus (Avato et al. 2006; Khan et al. 2018).

\section{Nutritional and mineral profiles of the edible Tetrastigma species}

Tetrastigma harmandii and T. loheri species are utilized for food because of their edible sour leaves (Morton and Collectanea, 1968). This study is the first report on the nutritional profiles of these two edible species (Table 8). Tetrastigma harmandii was found to be deficient in nitrogen, low phosphorus, high potassium, and sufficient calcium, manganese, iron, zinc, and copper contents. On the other hand, T. loheri was found to be deficient in nitrogen and phosphorus, high potassium, low calcium, sufficient manganese, iron, and zinc, and high copper content.

Per $100 \mathrm{~g}$ dry weight of Tetrastigma leaves, T. loheri contained higher crude protein, crude fat, and crude fiber than T. harmandii with $6.91 \%, 0.94 \%$, and $22.2 \%$ more crude protein, crude fat, and crude fiber, respectively. In contrast, $T$. harmandii contained more macronutrients and micronutrients compared to $T$. loheri. Tetrastigma harmandii contained $0.72 \%$ more nitrogen, $0.04 \%$ more phosphorus, $0.10 \%$ more calcium, $3.0 \mathrm{ppm}$ higher manganese, $84.0 \mathrm{ppm}$ more iron, and $19.0 \mathrm{ppm}$ more zinc content than T. loheri. However, T. loheri contained $0.26 \%$ more potassium and $37.0 \mathrm{ppm}$ more copper than $T$. harmandii. 
Table 5. Soil chemical characteristics of the Tetrastigma species growing environment.

\begin{tabular}{|c|c|c|c|c|c|c|c|c|}
\hline \multirow{3}{*}{ Species } & \multicolumn{8}{|c|}{ Soil chemical characteristics* } \\
\hline & \multirow{2}{*}{ pH } & \multirow{2}{*}{ OM (\%) } & \multirow{2}{*}{$\begin{array}{c}\begin{array}{c}\text { Available } \\
\text { phosphorus } \\
\text { (ppm) }\end{array} \\
\end{array}$} & \multirow{2}{*}{$\begin{array}{c}\text { Available } \\
\text { potassium } \\
(\text { ppm })\end{array}$} & \multicolumn{4}{|c|}{ Trace elements (ppm) } \\
\hline & & & & & $\mathbf{C u}$ & Zn & $\mathbf{F e}$ & Mn \\
\hline T. ellipticum & $3.17-4.44$ & $3.85-4.0$ & $7.90-14.0$ & $190.0-288.0$ & $0.44-1.76$ & $0.38-0.60$ & $19.20-126.40$ & $2.40-6.20$ \\
\hline Merr. & \pm 0.401 & \pm 0.050 & \pm 1.845 & \pm 28.449 & \pm 0.070 & \pm 0.416 & \pm 1.097 & \pm 31.085 \\
\hline T. harmandii & $5.25-6.71$ & $0.41-3.99$ & $20.80-100.0$ & 296.0-707.0 & $0.28-2.28$ & $0.48-1.38$ & $7.60-26.20$ & $5.20-37.60$ \\
\hline Planch. & \pm 0.428 & \pm 1.059 & \pm 25.668 & \pm 128.686 & \pm 0.282 & \pm 0.616 & \pm 9.565 & \pm 5.370 \\
\hline T. loheri & $4.34-6.46$ & $1.79-4.02$ & $2.90-16.40$ & $311.0-815.0$ & $0.72-3.90$ & $0.42-3.46$ & $10.80-47.80$ & $6.20-31.40$ \\
\hline Gagnep. & \pm 0.676 & \pm 0.712 & \pm 3.962 & \pm 152.998 & \pm 0.973 & \pm 0.940 & \pm 7.545 & \pm 12.170 \\
\hline
\end{tabular}

Note: $\mathrm{n}: 5$, mean \pm Std. Error

Table 6. Phytochemical screening of three Tetrastigma species leaf crude extracts

\begin{tabular}{lcccccccc}
\hline \multirow{2}{*}{ Species } & \multicolumn{9}{c}{ Plant Secondary Products* } \\
\cline { 2 - 8 } & ALK & FLV & PHE & TRP & ANT & TNS & STD & SPN \\
\hline Tetrastigma ellipticum Merr. & + & + & + & + & + & + & - & - \\
Tetrastigma harmandii Planch. & - & - & + & + & - & + & - & + \\
Tetrastigma loheri Gagnep. & - & - & + & + & - & + & - & - \\
\hline
\end{tabular}

Note: *ALK: alkaloids, FLV: flavonoids, PHE: phenols, TRP: terpenoids, ANT: anthocyanin, TNS: tannins, STD: steroids, SPN: saponins

Table 7. Antibacterial activity of leaf ethanolic extracts of three Tetrastigma species

\begin{tabular}{lccccccc}
\hline \multicolumn{1}{c}{ Species } & \multicolumn{6}{c}{ Zone of inhibition (mm)* } \\
\cline { 2 - 8 } & SA & EC & PA & EF & KP & KA & AB \\
\hline Tetrastigma ellipticum Merr. & 6.0 & 6.0 & 6.0 & 6.0 & 6.0 & 6.0 & 6.0 \\
Tetrastigma harmandii Planch. & 10.0 & 6.0 & 6.0 & 6.0 & 6.0 & 9.0 & 6.0 \\
Tetrastigma loheri Gagnep. & 6.0 & 6.0 & 6.0 & 6.0 & 6.0 & 6.0 & 6.0 \\
\hline
\end{tabular}

Note: Control (distilled water): $6.0 \mathrm{~mm}, \mathrm{n}=3, *(<10 \mathrm{~mm})$ may be expressed as inactive, $(10-13 \mathrm{~mm})$ partially active, $(14-19 \mathrm{~mm})$ active, (> $19 \mathrm{~mm})$ very active. SA: Staphylococcus aureus, EC: Escherichia coli, PA: Pseudomonas aeruginosa, EF: Enterococcus faecium, KP: Klebsiella pneumoniae, KA: Klebsiella aerogenes, AB: Acinetobacter baumannii

Table 8. Nutritional and mineral composition of Tetrastigma harmandii and T. loheri growing in northeastern Cagayan, Philippines

\begin{tabular}{|c|c|c|c|c|c|c|c|c|c|c|c|}
\hline \multirow[b]{2}{*}{ Species } & \multicolumn{11}{|c|}{ Nutritional and mineral content*** } \\
\hline & $\begin{array}{c}\text { CP } \\
(\%)\end{array}$ & $\begin{array}{l}\text { CF } \\
(\%)\end{array}$ & $\begin{array}{c}\text { CFb } \\
(\%)\end{array}$ & $\begin{array}{c}\mathbf{N} \\
(\%)\end{array}$ & $\begin{array}{c}\mathbf{P} \\
(\%)\end{array}$ & $\begin{array}{c}\mathbf{K} \\
(\%)\end{array}$ & $\begin{array}{c}\text { Ca } \\
(\%)\end{array}$ & $\begin{array}{c}\text { Mn } \\
(\mathbf{p p m})\end{array}$ & $\begin{array}{c}\mathbf{F e} \\
(\mathbf{p p m})\end{array}$ & $\begin{array}{c}\mathbf{Z n} \\
(\mathbf{p p m})\end{array}$ & $\underset{(\mathbf{p p m})}{\mathbf{C u}}$ \\
\hline Tetrastigma harmandii Planch. & 3.80 & 1.37 & 5.20 & 1.99 & 0.18 & 3.28 & 0.30 & 28.0 & 207.0 & 41.0 & 9.0 \\
\hline Tetrastigma loheri Gagnep. & 10.71 & 2.31 & 27.40 & 1.27 & 0.14 & 3.54 & 0.20 & 25.0 & 123.0 & 22.0 & 46.0 \\
\hline
\end{tabular}

Note: $* * \mathrm{CP}$ : crude protein, $\mathrm{CF}$ : crude fat, $\mathrm{CFb}$ : crude fiber

\section{ACKNOWLEDGEMENTS}

This study was funded by the Cagayan State University and supported by Local Government Units of Lal-lo, Aparri, Camalaniugan, Buguey, Santa Teresita, Gonzaga, and Santa Ana in Cagayan; Coast Guard Station Aparri; Coast Guard Sub-Station Santa Ana, Cagayan; Central Analytical Laboratory of the Cagayan State UniversityAndrews Campus; and the Regional Soils Laboratory and Regional Food Technology Development and Incubation Center of the Cagayan Valley Integrated Agricultural Laboratory, Department of Agriculture Region 2. The Tetrastigma species diversity and environmental assessment were participated in by the staff and officers of the Municipal Environment and Natural Resources Office (MENRO) and Barangay Officials of the said municipalities. The diversity map was done with the assistance of Mr. Benedict S. Hardy. Transportation going to the different municipalities and study sites was assisted by Mr. Efren Dela Cruz.

\section{REFERENCES}

Adarsh Krishna TP, Ajeesh Krishna TP, Sanyo Raj VN, Juliet S, Nair SN, Ravindran R, Sujith S. 2013. Evaluation of phytochemical constituents and proximate contents of the ethanolic leaf extract of Tetrastigm aleucostaphylum (Dennst.) Alstone (Vitaceae) found in Western Ghats of Kerala, India. Res J Pharmaceut Sci 2 (10): 1-6. 
Avato P, Bucci R, Tava A, Vitali C, Rosato A, Bialy Z, Jurzysta M. 2006. Antimicrobial activity of saponins from Medicago sp. structure-activity relationship. Phytother Res 20 (6): 454-457. DOI: $10.1002 /$ ptr. 1876 .

Brown, William Henry. 1920. Minor products of Philippine forests. Bureau of Printing, Manila.

Carag HM, Buot Jr. IE. 2017. A checklist of the orders and families of medicinal plants in the Philippines. Sylvatrop Tech J Philippine Ecosyst Nat Res 27 (1\&2): 49-59.

Chen P, Chen L, Wen J. 2011. The first phylogenetic analysis of Tetrastigma (Miq.) Planch, the host of Rafflesiaceae. Taxon 60(2): 499-512. DOI: 10.1002/tax.602017.

Ding F, Liu J, Du R, Yu Q, Gong L, Jiang H, Rong R. 2019. Qualitative and quantitative analysis for the chemical constituents of Tetrastigma hemsleyanum Diels et Gilg. using Ultra-High Performance Liquid Chromatography/Hybrid Quadrupole-Orbitrap Mass Spectrometry and preliminary screening for Anti-Influenza Virus components. Evid Based Compl Altern Med. DOI: 10.1155/2019/9414926.

Guevarra BQ. 2005. A Guidebook to Plant Screening: Phytochemical and Biological. UST Publishing House, España, Manila, Philippines.

Habib S, Dang VC, Ickert-Bond SM., Wen J, Chen ZD, Lu LM. 2018 Evolutionary trends in Tetrastigma (Vitaceae): Morphological diversity and taxonomic implications. J Syst Evol 56 (4): 360-373. DOI: $10.1111 /$ jse. 12309

Habib S, Dang VC, Ickert-Bond SM, Zhang JL, Lu LM, Wen J, Chen ZD. 2017. Robust phylogeny of Tetrastigma (Vitaceae) based on ten plastid DNA regions: Implications for infrageneric classification and seed character evolution. Front. Plant Sci 8: 590. DOI 10.3389/fpls.2017.00590

Hammer Ø, Harper DAT, Ryan PD. 2001. Past: Paleontological Statistics Software Package for Education and Data Analysis. Paleontologica Electronica 4: 9.

Horneck DA, Sullivan DM, Owen JS, Hart JM. 2011. Soil tes interpretation guide. Oregon State University Extension Service, Corvallis, USA.

Jones JB. 1967. Interpretation of plant analysis for several agronomic crops. In: Dinauer RC (eds.). Soil Testing and Plant Analysis. Part II Plant analysis. Soil Science Society of America, Madison, Wisc.

Khan MI, Ahhmed A, Shin JH, Baek JS, Kim MY, Kim JD. 2018. Green tea seed isolated saponins exert antibacterial effects against various strains of gram-positive and gram-negative bacteria, a comprehensive study in vitro and in vivo. Evid Based Compl Altern Med. DOI: $10.1155 / 2018 / 3486106$

Lianah L, Krisantini K, Sopade P. 2015. Status of traditional herb Tetrastigma glabratum (Blume). Planch in Mt Prau, Central Java, Indonesia. J Pharmacogn Phytochem 4 (4): 179-184.

Ma D, Li W, Ma Z, He L, Jiang F, Ding Z. 2012. Anti-liver damage activity analysis of polysaccharide in radix Tetrastigmatis hemsleyani. J Med Res 41 (1): 33-36.

Maghirang RG, Oraye CD, Antonio MA, Cacal MS, City B. 2018 Ethnobotanical studies of some plants commonly used as vegetables in selected provinces of the Philippines. J Nat Stud 17 (2): 30-43.

Morton JF, Collectanea M. 1968. Tropical fruit tree and other exotic foliage as human food. Proc Florida State Hort Soc 81: 318-329.

Motsara MR, Roy RN. 2008. Guide to laboratory establishment for plant nutrient analysis. Food and Agriculture Organization of the United Nations, Rome, Italy.

Pelser PB, Nickrent DL, Barcelona JF. 2016. Untangling a vine and its parasite: Host specificity of Philippine Rafflesia (Rafflesiaceae). Taxon 65(4): 739-758. DOI: 10.12705/654.4.

Quisumbing E. 1951. Medicinal Plants of the Philippines. Bureau of Printing, Manila, Philippines.

Wen J, Lu LM, Boggan JK. 2013. Diversity and evolution of Vitaceae in the Philippines. Philipp J Sci 142 (3): 223-244.

Wen J. 2007. Vitaceae. In: Kubitzki K (eds). Flowering Plants-Eudicots. Springer, Berlin, Heidelberg. DOI: 10.1007/978-3-540-32219-1_54

Xu C, Ding G, Fu J, Jia M, Zhang R, Lou XM. 2008. Immunoregulatory effects of ethyl-acetate fraction of extracts from Tetrastigma hemsleyanum Diels et. Gilg on immune functions of ICR mice. Biomed Environ Sci 21 (4): 325-331. DOI: 10.1016/S08953988(08)60050-1.

Yahya AF, Hyun JO, Lee JH, Sun BY, Lapitan PG. 2010. Distribution pattern, reproductive biology, cytotaxonomic study and conservation of Rafflesia manillana in Mt. Makiling, Laguna, Philippines. J Trop For Sci 22: 118-126.

Zhong X, Mao Q, Huang Z, Wei J. 2006. Protective effect and acute toxicity of Tetrastigma hemsleyanum extract on mice with acute liver injury induced by carbon tetrachloride. Chinese Traditional Patent Medicine 28 (3): 422-424. 